\title{
Perbedaan Asupan Zat Energi dan Aktivitas Fisik Pada Status Obesitas Pada Balita di Desa Mlati Kecamatan Mojo Kabupaten Kediri
}

\section{Differences in Energy Nutrition and Physical Activity Intake on Obesity Status in Toddlers in Mlati Village, Mojo District, Kediri Regency}

\author{
Bagus Ahmad Nur Abdillah*1, Merryana Adriani ${ }^{1}$, Candraningtyas Hermadani ${ }^{2}$
}

\begin{abstract}
ABSTRAK
Latar belakang: Obesitas mempunyai dampak buruk terhadap tumbuh kembang anak, terutama aspek perkembangan psikososial. Setiap tahunnya angka kejadian obesitas pada balita terus meningkat, maka dari itu diperlukan pengetahuan orang tua tentang obesitas pada balita. Masalah gizi tersebut disebabkan oleh ketidakseimbangan asupan makan dan aktivitas fisik.

Tujuan: Penelitian ini bertujuan untuk mengetahui perbedaan asupan energi dan aktivitas fisik pada balita obesitas dan non obesitas.

Metode: Penelitian ini merupakan penelitian observasional analitik dengan desain studi case control. Total sampel penelitian ini adalah 70 balita dengan jumlah pada setiap kelompok sebesar 35 balita. Pengumpulan data menggunakan penimbangan berat badan dan pengukuran tinggi badan, Analisis data menggunakan uji Mann Whitney dan uji T independent.

Hasil: Penelitian menunjukkan tidak ada perbedaan signifikan pada asupan energi $(\mathrm{p}=1,000)$ dan pada aktivitas fisik $(\mathrm{p}=0,173)$ antara balita obesitas dan non obesitas.

Kesimpulan: Tidak terdapat perbedaan signfikan antara asupan energy dan aktifitas fisik pada kelompok status gizi balita obesitas maupun non obesitas. Keterbatasan dari penelitian ini adalah instrumen untuk menggali data keragaman pangan menggunakan 24-h food recall dan food frequency questionaire, sehingga kemungkinan terjadi bias data untuk mengingat jenis makanan yang dikonsumsi oleh responden dari ibu responden.Selain hal tersebut, masih sedikit sekali penelitian mengenai faktor lingkungan terhadap aktifitas fisik pada balita. Sehingga mengakibatkan kurangnya informasi pola aktifitas fisik balita yang tinggal di suatu wilayah tertentu.
\end{abstract}

Kata kunci: aktivutas fisik, asupan energi, balita, obesitas

\section{ABSTRACT}

Background: Obesity has a negative impact on child development, especially on psychosocial aspects. Every year the incidence of obesity in children under five continues to increase, therefore it requires parents' knowledge about obesity in infants. Nutritional problems are caused by imbalances in food intake and physical activity.

Objective: This study aims to determine differences in energy intake and physical activity in obese and nonobese children.

Method: This study was an analytic observational study with case control design. The total sample of this study was 70 toddlers with a number in each group of 35 toddlers. Data collection using weight weighing and height measurement, data analysis using Mann Whitney test and independent T test.

Results: The study showed that there was no significant difference in energy intake $(p=0,000)$, whereas in physical activity $(p=0,173)$ there was no significant difference between obese and non-obese children.

Conclusion: There was no significant difference between energy intake and physical activity in the nutritional status group of obese and non obese respondents. The limitation of this study is the instrument to explore food diversity data using 24-h food recall and food frequency quest questionnaire, so that the possibility of data bias occurs to remember the type of food consumed by respondent from the mother of respondent. Towards physical activity in infants, resulting in a lack of information on the pattern of physical 
activity of toddlers who live in a certain area.

Keywords: energy intake, obesity, physical activity, toddlers.

*Koresponden:

Bagus.abdillah4@gmail.com

Bagus Ahmad Nur Abdillah

${ }^{1}$ Departemen Gizi, Fakultas Kesehatan Masyarakat, Universitas Airlangga, Kampus C Mulyorejo, 60115,

Surabaya, Jawa Timur, Indonesia

${ }^{2}$ Departemen Gizi, Fakultas Kesehatan Masyarakat, Poltekkes Kementerian Kesehatan, Surabaya, Jawa Timur

\section{PENDAHULUAN}

Setiap tahunnya angka kejadian obesitas pada balita terus meningkat, maka dari itu diperlukan pengetahuan orang tua tentang obesitas pada balita. Lebih dari 2,1 miliar balita memiliki berat badan berlebih dan berat berlebih yang menyebabkan munculnya berbagai penyakit kronis seperti diabetes dan penyakit jantung(Who, 2010). Prevalensi kegemukan pada anak balita secara nasional berdasarkan indikator berat badan menurut tinggi badan mencapai $14 \%^{2}$. Berdasarkan tempat tinggal prevalensi kegemukan lebih tinggi diperkotaan dibandingkan dengan prevalensi dipedesaan yaitu berturut-turut 10,4 \% dan 8,1 \% (Penelitian and Pengembangan, 2010). Dari data riset kesehatan dasar di Jatim tercatat angka balita yang mengalami obesitas mencapai $17,1 \%$, sedangkan di Kabupaten Kediri jumlah angka obesitas pada anak sebanyak $13 \%$. Pada tahun 2010, balita di indonesia yang mengalami kelebihan berat badan mencapai $19,1 \%$ dan terus meningkat setiap tahunnya (Penelitian and Pengembangan, 2010).

Persentase ini sangat tinggi untuk kasus obesitas pada balita. Terjadinya obesitas merupakan dampak dari terjadinya kelebihan asupan energy dibandingkan dengan yang diperlukan oleh tubuh sehingga kelebihan asupan energy disimpan dalam bentuk lemak (Putri P.A, 2014). Selama ini sebagian masyarakat masih mempunyai anggapan bahwa balita yang gemuk menandakan balita yang sehat. Secara umum obesitas pada balita disebabkan karena kebiasaan pada pola makan, makanan siap saji salah satu contoh penyebabnya ${ }^{4}$. Obesitas mempunyai dampak terhadap tumbuh kembang anak, terutama aspek perkembangan psikososial.Selain itu dampak dari obesitas juga berpotensi mengalami berbagai penyakit yang menyebabkan kematian antara lain penyakit kardiovaskular, dan diabetes melitus,.Obesitas merupakan penyakit yang kompleks dan multifaktor yang penyebabnya belum diketahui secara pasti, diduga sebagian besar obesitas disebabkan oleh faktor hereditas yaitu anak yang memiliki satu orang tua yang obesitas meningkatkan risiko obesitas 3 kali lipat, tetapi risiko obesitas dapat meningkatkan 10 kali jika kedua orang tuanya obesitas(Pramudita, 2011). Beberapa faktor penyebab obesitas pada anak antara lain pemberian ASI, pemberian MP-ASI terlalu dini, dan asupan nutrisi yang berasal dari jenis makanan olahan serbainstan, minuman soft drink, makanan jajanan seperti makanan cepat saji/ fastfood yang tersedia digerai makanan (Sari, 2015). Penelitian ini bertujuan untuk membedakan asupan energi dan aktivitas fisik pada balita obesitas dan non obesitas di Desa Mlati, Kecamatan Mojo Kabupaten Kediri.

\section{METODE}

Jenis penelitian ini adalah penelitian observasi analitik, dengan desain case control. Case control adalah penelitian yang dilakukan dengan cara membandingkan antara dua kelompok yaitu kelompok kasus dan kelompok control (Notoatmodjo, 2010). Studi kasus kontrol dilakukan dengan mengindentifikasi kelompok kasus dan kelompok kontrol. Penelitian ini dilakukan di di Desa Mlati, Kecamatan Mojo, Kabupaten Kediri. Pengumpulan data dilakukan pada bulan Agustus 2018.

Populasi dalam penelitian ini adalah balita usia 2-5 tahun yang bertempat tinggal di Desa Mlati, Kecamatan Mojo, Kabupaten Kediri. Skrining dilakukan pada 152 balita dengan mengukur berat badan dan tinggi badannya. Balita yang memiliki Z-score BB/TB > 2SD di kategorikan sebagai balita obesitas (58 balita), sedangkan balita dengan Z-score BB/TB > 2SD - 2SD masuk dalam kategori non obesitas (94 balita) dipilih secara purposive dari masing-masing kelompok dengan pertimbangan lokasi rumah balita mudah di jangkau, tidak memiliki keluhan sakit dan kesediaan orang tua untuk di wawancarai. Unit penelitian ini adalah balita, sedangkan responden penelitian adalah ibu balita. Berdasarkan hasil perhitungan rumus Lemeshow, didapatkan jumlah sampel kontrol dan kasus $1: 1$ yaitu berjumlah 35 balita. Oleh karena itu, dipilih 35 sampel sebagai kasus dan 35 sampel sebagai kontrol. Variabel yang digunakan pada penelitian ini yaitu variabel dependent dan independen. Variabel dependen pada penelitian ini adalah kejadian obesitas pada balita yang ditentukan dari data antropometri timbangan digital dan microtoise . Data 
antropometri terdiri dari berat badan dan tinggi badan yang kemudian dikelompokkan dan dinilai sesuai standar WHO (Z-score) dengan menggunakan software WHO Anthroplus, yaitu: non obesitas (-2,0 Sd s/d 2,0 $\mathrm{SD}$, dan obesitas $(+3 \mathrm{SD}$. Variabel independent pada penelitian ini adalah asupan energi yang didapat melalui wawancara dengan menggunakan food recall $2 \times 24$ jam kemudian dijumlahkan dan dikonversikan menjadi energi yang dinyatakan dalam kalori menggunakan software Nutrisurvey. Asupan energi dalam penelitian ini dapat diketahui dari jumlah asupan gizi rata-rata per hari yang dikonsumsi oleh kelompok obesitas dan kelompok non obesitas. Asupan energi minimal merupakan asupan energi minimal yang dikonsumsi oleh anggota kelompok obesitas maupun non obesitas, sedangkan asupan energi maksimal merupakan asupan energi maksimal yang dikonsumsi oleh anggota kelompok obesitas maupun non obesitas. Pengukuran fisik dilakukan dengan metode wawancara terstruktur menggunakan panduan rujukan nilai Physical Activity Rate $(P A R)$ dan Physical Activity Level (PAL). Metode ini meliputi kegiatan apa saja yang dilakukan sampel selama 24 jam beserta alokasi waktu yang dilakukan pada setiap aktivitas menggunakan kuesioner yang dinyatakan dalam angkah dan dapat dikategorikan tingkat aktivitas fisik (PAL), rendah (1,40-1,69), sedang $(1,70-1,99)$ berat $(2,00-2,40)$.

Analisis statistika yang digunakan untuk mengolah data penelitian ini yaitu analisis deskriptif dan analisis inferensial. Analisis deskriptif digunakan untuk mendapatkan gambaran pada setiap variabel yang diteliti, meliputi karakteristik balita (usia, jenis kelamin), karakteristik orang tua (tingkat pendidikan, pekerjaan,), pengetahuan gizi ibu, asupan energi, dan aktivitas fisik balita. Sedangkan analisis inferensial yang digunakan untuk mengetahui menilai perbedaan tingkat asupan energi dan aktivitas fisik antara balita yang berstatus obesitas dengan yang berstatus non obesitas adalah Mann Whitney apabila variabel berskala ordinal (Kuntoro, 2007). dan menggunakan uji $\mathrm{T}$ independen apabila variabel berskala rasio (Kuntoro, 2007). Data diolah menggunakan IBM SPSS Statistics 21.0 for Windows.

Penelitian ini telah disetujui oleh Komisi Etik Penelitian Kesehatan Fakultas Kesehatan Masyarakat Universitas Airlangga (No. 185- KEPK), serta ijin dari Bakesbangpol Kota Surabaya (No. 070/1462/436.8.5/2018.

\section{HASIL DAN PEMBAHASAN}

Karakteristik orang tua yang diteliti meliputi pendidikan orang tua, pekerjaan orang tua, dan pengetahuan ibu. Berdasarkan hasil penelitian menurut Tabel 1, untuk karakteristik pendidikan orang tua, sebagian besar orang tua memiliki tingkat pendidikan tamat SMA baik pada kelompok obesitas maupun non obesitas. Hal ini menunjukkan bahwa sebagian besar tingkat pendidikan orang tua responden sudah baik. Pendidikan bisa mempengaruhi keputusan dalam konsumsi melalui pemilihan bahan pangan yang dilakukan orangtua. Ibu rumah tangga sering berperan menjadi penentu dan pengatur konsumsi makan dalam keluarga. Oleh sebab itu tingkat pendidikan, khususnya pendidikan wanita terutama ibu dapat memengaruhi derajat kesehatan (Atmarita, 2004). Dilihat dari pendidikan orang tua responden, dapat disimpulkan bahwa sebagian besar orang tua responden telah memiliki pengetahuan yang cukup untuk memilih dan mengatur makanan yang akan dikonsumsi anaknya.

Selanjutnya orang tua pada kelompok balita obesitas sebagian besar pekerjaan ayah sebanyak $35 \%$ adalah pegawai Swasta dan Wiraswasta sementara itu pada kelompok non obesitas lebih dari separuhnya bekerja sebagai wiraswasta. Sebagian besar ibu merupakan ibu rumah tangga baik di kelompok obesitas maupun non obesitas. Seseorang yang bekerja cenderung memiliki pengetahuan yang lebih baik daripada yang tidak bekerja. Pekerjaan orangtua, terutama ibu mempunyai pengaruh besar terhadap perkembangan anak, ibu yang baik dapat menjaga dan melakukan tugas di rumah, memperhatikan perawatan anak baik makanan atau kesehatan, membina dan membimbing anak (Meirita, Martianto, 2000).

Dilihat dari pekerjaan orangtua responden, dapat disimpulkan bahwa sebagian besar orangtua responden telah mampu memenuhi kebutuhan makanan anak dengan kualitas dan kuantitas yang tinggi. Sedangkan berdasarkan karakteristik pengetahuan ibu, sebagian besar lebih dari separuh ibu memiliki memiliki tingkat pengetahuan gizi yang sedang baik kelompok obesitas maupun non obesitas. Ibu pada kelompok obesitas memiliki proporsi tingkat pengetahuan yang baik sedikit lebih tinggi di bandingkan kelompok non obesitas $(54,3 \%$ dan $65,7 \%)$.

Semakin banyak informasi yang diperoleh mengenai gizi, kemampuan dalam memilih makanan dan perilaku konsumsi akan semakin baik. Pengetahuan orang tua juga dapat berperan dalam meningkatkan pengetahuan anak dan memberikan penanaman kebiasaan perilaku konsumsi yang baik sejak dini. Jadi dari hasil penelitian ini dapat disimpulkan bahwa sebagian besar pengetahuan gizi ibu balita sudah baik sehingga mampu memilih makanan dengan gizi seimbang untuk anak. 
Tabel 1. Karakteristik Orang Tua

\begin{tabular}{|c|c|c|c|c|c|c|c|c|}
\hline \multirow{3}{*}{$\underline{\text { Karakteristik }}$} & \multicolumn{4}{|c|}{ Obesitas } & \multicolumn{4}{|c|}{ Non-Obesitas } \\
\hline & \multirow{2}{*}{$\frac{\text { Ayah }}{\underline{\mathbf{n}}}$} & \multicolumn{3}{|c|}{ Ibu } & \multirow{2}{*}{$\frac{\text { Ayah }}{\underline{\mathbf{n}}}$} & \multicolumn{3}{|c|}{ Ibu } \\
\hline & & $\%$ & $\overline{\underline{n}}$ & $\%$ & & $\underline{\%}$ & $\overline{\underline{n}}$ & $\underline{\%}$ \\
\hline \multicolumn{9}{|l|}{ Pendidikan } \\
\hline$\overline{\text { Tamat SD/MI }}$ & 0 & 0 & 2 & 5,7 & 0 & 0 & 1 & 2,9 \\
\hline Tamat SMP/MTS & 3 & 8,6 & 7 & 20,0 & 2 & 5,7 & 9 & 26,5 \\
\hline Tamat SMA/SMK & 29 & 82,6 & 22 & 62,9 & 31 & 88,6 & 23 & 65,7 \\
\hline $\begin{array}{l}\text { Tamat } \\
\text { D1/D2/D3/PT }\end{array}$ & 3 & 8,6 & 4 & 11,4 & 2 & 5,7 & 2 & 5,7 \\
\hline Total & 35 & 100 & 35 & 100 & 35 & 100 & 35 & 100 \\
\hline \multicolumn{9}{|l|}{ Pekerjaan } \\
\hline Tidak Bekerja & 1 & 2,9 & 25 & 71,4 & 0 & 0 & 29 & 82,4 \\
\hline Pegawai/Swasta & 12 & 34,3 & 6 & 17,1 & 5 & 14,3 & 1 & 2,9 \\
\hline PNS/TNI/POLRI & 1 & 2,9 & 0 & 0 & 2 & 5,7 & 0 & 0 \\
\hline Wiraswasta & 13 & 37,1 & 3 & 8,6 & 19 & 52,9 & 3 & 8,8 \\
\hline Lain-lain & 8 & 22,9 & 1 & 2,9 & 9 & 26,5 & 2 & 5,9 \\
\hline Total & 35 & 100 & 35 & 100 & 35 & 100 & 35 & 100 \\
\hline \multicolumn{9}{|l|}{ Pengetahuan Ibu } \\
\hline Baik & & & 15 & 42,9 & & & 12 & 34,3 \\
\hline Sedang & & & 19 & 54,3 & & & 23 & 65,7 \\
\hline Kurang & & & 1 & 2,9 & & & 0 & 0 \\
\hline Total & & & 35 & 100 & & & 35 & 100 \\
\hline
\end{tabular}

Tabel 2. Karakteristik Balita

\begin{tabular}{|c|c|c|c|c|}
\hline \multirow{2}{*}{ Karakteristik } & \multirow{2}{*}{$\begin{array}{c}\text { Obesitas } \\
\text { n }\end{array}$} & \multicolumn{3}{|c|}{ Non-Obesitas } \\
\hline & & $\%$ & n & $\%$ \\
\hline \multicolumn{5}{|l|}{ Umur } \\
\hline 24 - 35 Bulan & 22 & 62,9 & 20 & 57,1 \\
\hline $36-47$ Bulan & 10 & 28,6 & 14 & 31,4 \\
\hline 48- 59 Bulan & 3 & 8,6 & 4 & 11,4 \\
\hline Total & 35 & 100 & 35 & 100 \\
\hline \multicolumn{5}{|l|}{ Jenis Kelamin } \\
\hline Laki-laki & 19 & 54,3 & 19 & 54,3 \\
\hline Perempuan & 16 & 45,7 & 16 & 45,7 \\
\hline Total & 35 & 100 & 35 & 100 \\
\hline \multicolumn{5}{|c|}{ Tabel 3. Variabel Aktivitas Fisik dan Tingkat Konsumsi Zat Gizi Makro } \\
\hline Variabel & Obesitas & Non-Obesitas & $\mathbf{O R}$ & P-value \\
\hline \multicolumn{5}{|l|}{ Aktivitas Fisik } \\
\hline Rendah & 8 & 5 & 1,78 & 0,173 \\
\hline Sedang dan Berat & 27 & 30 & & \\
\hline \multicolumn{5}{|l|}{ Energi } \\
\hline Kurang $(<77 \%$ AKG) & 3 & 4 & 0,727 & 1,000 \\
\hline Cukup (>77\% AKG) & 32 & 31 & & \\
\hline \multicolumn{5}{|l|}{ Protein } \\
\hline Kurang (<77\% AKG) & 2 & 3 & 0,646 & 1,000 \\
\hline Cukup (>77\% AKG) & 33 & 32 & & \\
\hline \multicolumn{5}{|l|}{ Lemak } \\
\hline Kurang (<77\% AKG) & 2 & 2 & 1,0 & 1,000 \\
\hline Cukup (>77\% AKG) & 33 & 33 & & \\
\hline \multicolumn{5}{|l|}{ Karbohidrat } \\
\hline Kurang (<77\% AKG) & 9 & 7 & 1,38 & 0,777 \\
\hline Cukup (>77\% AKG) & 26 & 28 & & \\
\hline
\end{tabular}




\begin{tabular}{lll}
\hline Total & 35 & 35
\end{tabular}

Pada penelitian berikut, karakteristik balita terbagi menjadi, umur dan jenis kelamin. Dari hasil penelitian diketahui bahwa sebagian besar responden obesitas umur 2-5 tahun yaitu sebanyak $(67,6 \%)$ dan responden non obesitas umur 2-5 tahun yaitu $(58,8 \%)$. Responden dengan status gizi obesitas sebagian besar pada balita usia 3 tahun. Sedangkan pada non obesitas sebagian besar pada balita usia 3 tahun. Hasil penelitian ini menunjukkan bahwa sebagian besar responden obesitas dan non obesitas adalah berjenis kelamin laki-laki yaitu sebesar 52,9\% sedangkan perempuan sebesar 47,1\%. Jenis kelamin menentukan besar kecilnya kebutuhan gizi seseorang. Presentase anak laki-laki yang kelebihan berat badan lebih tinggi daripada anak perempuan.

Hal ini sejalan dengan penelitian Dewi dan Sidiartha, yang menyebutkan bahwa persentase lakilaki yang mengalami obesitas $(26 \%)$ lebih banyak dibandingkan perempuan ${ }^{10}$. Hal ini juga sejalan dengan beberapa penelitian yang menyebutkan bahwa obesitas pada anak laki-laki lebih sering terjadi daripada pada anak perempuan (Ogden et al., 2016). Berdasarkan tinjauan literatur, jenis kelamin memiliki hubungan dengan gizi lebih. Hal ini disebabkan karena perbedaan pola makan dan asupan gizi antara anak laki-laki dan perempuan. Pada anak laki-laki cenderung mengonsumsi lebih banyak makanan sehingga memungkinkan asupan energi lebih besar yang secara langsung dapat berkontribusi terhadap kejadian gizi lebih (Almatsier, 2011).

\section{Asupan Energi}

Berdasarkan uji Mann Whitney dan uji T Independent diketahui bahwa tidak ada perbedaan signifikan antara asupan energi dengan status gizi balita. Nilai p yang menunjukkan tidak adanya perbedaan antara tingkat asupan energi dengan status gizi sebesar 1,000. Tidak ada hubungan ini kemungkinan disebabkan adanya faktor lain yang mempengaruhi asupan energi dan status gizi seperti sanitasi lingkungan sehat secara tidak langsung mempengaruhi kesehatan balita yang pada akhirnya dapat mempengaruhi kondisi status gizi anak ${ }^{21}$.

Asupan energi ini juga dipengaruhi oleh besarnya jumlah asupan protein, lemak dan karbohidrat. yang menunjukkan tidak ada hubungan antara asupan karbohidrat dengan status gizi. Hal ini kemungkinan disebabkan karena adanya faktor penyebab lainnya seperti keberadaan infeksi yang turut mempengaruhi status gizi dan belum dapat ditentukan dalam penelitian. Nilai $p$ yang menunjukkan tidak adanya hubungan antara tingkat asupan karbohidrat dengan status gizi sebesar 0,777. Berdasarkan hasil recall $2 \times 24$ jam diperoleh hasil bahwa makanan sumber karbohidrat yang sering dikonsumsi responden adalah nasi, mie dan juga roti. Konsumsi energi yang kurang bervariasi dan jumlah porsinya sedikit akan berpengaruh terhadap asupan ${ }^{21}$. Nilai $\mathrm{p}$ yang menunjukkan tidak ada hubungan antara tingkat asupan lemak dengan status gizi sebesar 1,000. Penelitian ini menunjukkan tidak adanya hubungan antara lemak dengan status gizi yang disebabkan karena porsi makan yang tidak sesuai dengan kebutuhan. Lemak banyak terdapat dalam bahan makanan yang bersumber dari hewani, misalnnya daging berlemak, jeroan, dan sebagainya, sedangkan minyak banyak digunakan untuk memasak atau menggoreng. Hasil analisis juga menunjukkan bahwa asupan protein bukan merupakan faktor risiko terjadinya obesitas. Asupan protein merupakan faktor protektif, disini asupan protein digunakan sebagai energi. Hal ini disebabkan asupan lemak dan karbohidrat tidak cukup sehingga memecah protein. Apabila tubuh kekurangan zat energi, fungsi protein untuk menghasilkan energi atau untuk membentuk glukosa akan didahulukan. Sehingga konsumsi protein yang berlebih tidak dapat menyebabkan sesorang menjadi obesitas. Asupan energi yang diperoleh dari konsumsi protein, lemak dan karbohidrat tidak dapat dijadikan satu-satunya faktor penyebab terjadinya obesitas. Perlu diperhatikan juga aktifitas fisik sanitasi lingkungan dan kesehatan dari balita itu sendiri.

Pada hasil penelitian diperoleh rata2 asupan energi pada balita obesitas sebesar $(1446,32 \pm 179,88)$ dan $(1201,46 \pm 122,27)$ pada balita non obesitas. Energi didapatkan dari asupan makan dan minum, yaitu dari zat gizi makro yang terdiri atas protein, lemak dan karbohidrat. Setiap 1 gram protein, lemak dan karbohidrat akan diubah menjadi $4 \mathrm{kkal}, 9 \mathrm{kkal}$, dan $4 \mathrm{kkal}$. Dalam penelitian ini menggunakan perbandingan asupan energi dengan AKG sesuai usia dan jenis kelamin yang kemudian dinyatakan dalam persen. Asupan gizi yang cukup tersebut mampu untuk memelihara dan meningkatkan kesehatan tubuh, bahkan mampu untuk menurunkan risiko terhadap penyakit tertentu (Hardinsyah, 2017).

Hasil penelitian menunjukkan bahwa tidak terdapat perbedaan yang signifikan pada tingkat konsumsi energi pada kedua kelompok.

Keterbatasan dari penelitian ini adalah instrumen untuk menggali data keragaman pangan menggunakan 24- $h$ food recall dan food frequency questinnaire, sehingga kemungkinan terjadi bias data untuk mengingat jenis makanan yang dikonsumsi oleh responden dari ibu responden. 


\section{Aktivitas Fisik}

Pada penelitian ini diperoleh bahwa lebih dari separuh balita obesitas maupun non obesitas samasama memiliki aktivitas fisik sedang. Hasil uji statistik dengan menggunakan Mann whitney test, tidak ada perbedaan aktivitas fisik antara kelompok balita obesitas dan balita non obesitas dengan nilai $\mathrm{p}=0,173$. Hasil tersebut sesuai dengan temuan data deskriptif dimana nilai median obesitas dan non obesitas samasama pada kategori sedang. Aktivitas fisik balita dinilai dengan menggunakan Form Recall Physical Activity. Aktivitas fisik yang diketahui adalah aktivitas yang dilakukan balita dalam kurun waktu sehari. Tiap item pertanyaan memiliki poin, dan kemudian dihitung rata-rata dari setiap poin di setiap pertanyaan. Tingkat Physical Activity Level (PAL) pada kelompok kasus dan kontrol tergolong sedang. Anak usia $2-5$ tahun berada pada masa anak menjadi sangat aktif dalam melakukan sedentary lifestyle. Lingkungan balita yang terletak di pedesaan membuat balita lebih bebas bermain bersama teman-teman sebayanya dan menemukan hal-hal baru. Sehingga aktivitas tidak banyak dilakukan dirumah saja,hal ini menjadi penyebab aktifitas balita cenderung sedang bagi balita obesitas maupun non obesitas. Hal ini sesuai dengan penelitian Sugiatmi dan Dian, penelitian dilakukan di salah satu daerah dengan letak berada di perkotaan dan dekat dengan mall,sehingga penelitian mengasumsikan adanya anak tersebut memiliki gaya hidup yang lebih berisiko obesitas dibanding di pedesaan ${ }^{22}$. Balita di perkotaan sangat jarang bermain diluar rumah karena ketiadaan lahan bermain, padatnya kendaraan berlalu-lalang dan rawan akan tindak kejahatan sehingga anak jarang melakukan kegiatan diluar rumah.Sebagian besar anak menghabiskan waktu di rumah dengan bermain menggunakan gadget ${ }^{3}$. Sebagian besar kegiatan yang dilakukan pada akhir minggu adalah pergi kepusat perbelanjaan dan makan bersama, atau bersantai di rumah.

Aktivitas fisik adalah setiap gerakan fisik sebagai hasil dari adanya kontraksi otot skeletal dan diukur sebagai pengeluaran energi ${ }^{14}$. Aktifitas fisik balita yang tinggal disuatu daerah tertentu akan menentukan pola perilaku dan kebiasaan hidupnya. Hal ini yang menyebabkan bahwa aktifitas fisik juga bukan satu-satunya faktor yang dapat membuat balita obesitas. Oleh karena itu, baik aktivitas fisik yang ringan maupun berat tidak dapat langsung mempengaruhi status gizi balita. Perlu untuk melihat faktorfaktor lainnya yang dapat mempengaruhi status gizi balita misalnya seperti lingkungan tempat tinggal,asupan energi dan makanan yang masuk ke dalam tubuh ${ }^{15}$.

\section{KESIMPULAN}

Berdasarkan hasil penelitian ini menunjukkan bahwa tidak terdapat perbedaan signfikan antara asupan energy dan aktifitas fisik pada kelompok status gizi responden obesitas maupun non obesitas. Asupan tidak dapat dijadikan sebagai satu-satunya faktor penyebab obesitas. Seharusnya memperhatikan pula aktifitas fisik, sanitasi lingkungan, dan kesehatan balita. Kemungkinan balita mengalami suatu infeksi atau intoleransi tertentu terhadap beberapa bahan makanan. Aktifitas fisik balita yang tinggal disuatu daerah tertentu akan menentukan pola perilaku dan kebiasaan hidupnya. Hal ini yang menyebabkan bahwa aktifitas fisik juga bukan satu-satunya faktor yang dapat membuat balita obesitas, sehingga perlu diteliti lebih lanjut. Keterbatasan dari penelitian ini adalah instrumen untuk menggali data keragaman pangan menggunakan 24-h food recall dan food frequency questinnaire, sehingga kemungkinan terjadi bias data untuk mengingat jenis makanan yang dikonsumsi oleh responden dari ibu responden. Selain hal tersebut, masih sedikit sekali penelitian mengenai faktor lingkungan terhadap aktifitas fisik pada balita, sehingga mengakibatkan kurangnya informasi pola aktifitas fisik balita yang tinggal di suatu wilayah tertentu.

\section{ACKNOWLEDGEMENT}

Peneliti mengucapkan terimakasih kepeda seluruh responden, Kepala Desa Mlati yang telah mengijinkan peneliti untuk melakukan penelitian di Desa tersebut.

\section{DAFTAR PUSTAKA}

Almatsier, S. (2011) Prinsip Dasar Ilmu Gizi. Jakarta: Pt Gramedia Pustaka Utama.

Atmarita, T. S. F. (2004) 'Analisis Situasi Gizi dan Kesehatan Masyrakat', Widyakarya Nasional Pangan, 8, pp. $1-37$.

Hardinsyah, S. D. (2017) Ilmu Gizi Teori dan Aplikasi. 1st edn. EGC. Kuntoro (2007) Metode Statistika. Surabaya: Pustaka Melati.

Meirita, Martianto, S. (2000) 'Hubungan Kuantitas dan Kualitas Pengasuhan Dengan Status Gizi Anak Bawah Lima Tahun Di Desa Rancamaya Kota Bogor', Media Gizi \& Keluarga, (2), pp. 23-27.

Notoatmodjo, S. (2010) 'Promosi Kesehatan Teori dan Aplikasi', in. Jakarta: PT Rineka Cipta.

Ogden, C. L. et al. (2016) 'HHS Public Access', Prevalence of Childhood and Adult Obesity in the United States, 311(8), pp. 806-814. doi: 10.1001/jama.2014.732.Prevalence. 
31 Media Gizi Kesmas, Vol 8, No 1 Juni 2019: Halaman: 23-31

Penelitian, B. and Pengembangan, D. A. N. (2010) 'Riset Kesehatan Dasar', Kementrian kesehatan RI. Pramudita, R. A. (2011) Faktor Resiko Obesitas Pada Anak Sekolah Dasar Di Kota Bogor. Institut Pertanian Bogor.

Putri P.A, N. E. (2014) 'Perbedaan Asupan Energi,Lemak,Serat Dan Aktivitas Fisik Pada Anak Obesitas Dan Non-Obesitas Usia 3-5 Tahun', Journal of Nutrition Collange, 3(1), pp. 150-157.

Sari, M. (2015) Tingkat pengetahuan ibu tentang obesitas pada balita di pkd ngudi waras jabung sragen karya tulis ilmiah. Sekolah Tinggi Ilmu Kesehatan Kusuma Husada.

Who (2010) 'Obesity : Preventing And Managing the Global Epidemic Report of a', 894. 